\title{
CSIRO is streamlined under new boss
}

Sydney. The new chief executive of Australia's giant Commonwealth Scientific and Industrial Research Organisation (CSIRO) has announced a number of key changes to the organization, including the removal of a complete layer of management.

After little more than a month as head of Australia's largest employer of scientists, Malcolm McIntosh has said that he intends to reshuffle CSIRO's basic operating units - its 36 divisions, employing 7,000 staff. High among those changes will be a reshaping of the Division of Animal Production, which McIntosh says would have been declared "insolvent" if it had been in the private sector.

In his first major announcement since taking control of the CSIRO in February, McIntosh said last week that its six institutes - an intermediate level of management between the divisions which carry out research, and the organization's headquarters - would be abolished on 1 July.

Four of the six current institute chiefs will become deputy chief executives and sit on an executive committee with McIntosh. This will meet several times a month, in contrast to the existing executive committee, made up of institute chiefs, which meets just once a month. The two other acting institute chiefs will return to other duties and await vacancies on the executive.

In addition to sitting on the executive committee, the four deputies will head loose groupings of divisions, called alliances, which will promote cross-divisional research. Although similar to the existing institutes, the alliances will not have any administrative structure or secretariat. All staff now employed by the institutes will moved to CSIRO headquarters, or to the divisions.

The abolition of the institutes has long been expected. Originally created about a decade ago to improve the coordination of the activities of CSIRO's divisions, they have since been widely condemned by staff, as well as a 1994 government inquiry, for simply adding to the organization's bureaucracy and paper work.

An internal management report to the CSIRO board in 1995 also recommended abolishing the institutes, among other changes, although it did not accept that the institutes had caused any difficulties. But the then acting chief executive, Roy Green, and the board declined to take any major action until the new chief executive had arrived.

The appointment of McIntosh, a physi-



cist and previously chief of defence procurement in the United Kingdom, was announced in July last year but he was only able to start his new job in February. He now faces the formidable task of rejuvenating an organization that is not only believed to be awash with paper work, but has recently seen a number of disputes between divisional research staff - including the divisional chiefs - and the CSIRO board.

The changes announced last week have been broadly welcomed by staff, although some have expressed reservations over the fact that the executive committee will include the same senior executives as previously, and concern that the alliances could still generate a considerable amount of bureaucratic paperwork.

One division that may face significant changes, including staff redundancies there have been reports that between 60 and 120 staff are thought to be under threat - is the Division of Animal Production. The division's A $\$ 13$ million (US\$9.6 million) a year budget relies heavily on funds from the wheat and sheep farming sectors. But with the collapse in wool prices two years ago, the wool sector has fallen on hard times, and such funds have dried up.

MacIntosh says that he hopes all changes immediately required will be finalized by the end of the financial year, but adds that they they will not be the last changes he will make. $\mathrm{He}$ adds that the divisional structure should evolve as circumstances change, and that mergers, demergers and even staff retrenchments could become a permanent feature.

Mark Lawson

\section{US tops international league in action on blood products}

Montreal. A survey by members of the law faculty at the University of Toronto of how seven industrialized countries - excluding Japan - responded to the HIV-tainted blood crisis in the mid-1980s rates the United States best and Switzerland worst in the promptness with which they implemented the two most important risk reducing measures into their distribution

They conclude that the performance of all seven countries "was far from exemplary, and exhibited serious institutional shortcomings leading to many readily avoidable deaths". This was due partly to social and cultural attitudes, including the view that AIDS was a disease confined to homosexuals, intravenous drug users and sexually promiscuous members of minority ethnic groups.

Outside the United States, AIDS was also viewed as primarily an "American disease", says that study. Only when all users of the blood system were "widely perceived to be at serious risk" did the institutions begin to respond effectively to the crisis.
In every country studied, institutions centrally involved persisted in denying risks of HIV contamination of the blood system well beyond the time when their existence had been scientifically proved. In many cases, "the vigour of these denials increased and persisted as a direct function of the extent to which the blood system was dominated by non-profit institutions," says the report.

The United States introduced heat treatment of blood products in October 1984 and the ELISA HIV screening test in May, 1985. In contrast, Switzerland did not use heat treatment until May, 1986, and the ELISA test until November 1985. Canada shared the worst-place rating with Switzerland in terms of the introduction date of ELISA.

The preliminary results of the study, carried out by Michael Trebilcock, Robert Howse and Ron Daniels of the law faculty's Centre for the Study of State and Market, were presented to a meeting at the university earlier this month. The full results are due to be published in the Virginia Law

\section{Review next autumn}

The survey's purpose was to attempt a comparative analysis of the performance of the sharply differing blood systems of the countries involved.

"Our aim is not to make an overall judgement about these systems, either against efficiency or other criteria, but to understand their capacity to respond to a crisis that threatened the integrity of the blood supply," say the authors of the study.

The authors say that British and French governments, as owners and operators of elements of the blood system, seemed much more protective of them than governments that had a less direct stake in their systems.

In Canada, where federal regulatory responsibility was well established, the financing arrangements entailed complex and interprovincial negotiations, and considerations of regional development, job creation and industrial policy, that eventually accomplished nothing and wasted millions of dollars, says the report. David Spurgeon 